The author reported no conflicts of interest.

The Journal policy requires editors and reviewers to disclose conflicts of interest and to decline handling or reviewing manuscripts for which they may have a conflict of interest. The editors and reviewers of this article have no conflicts of interest.

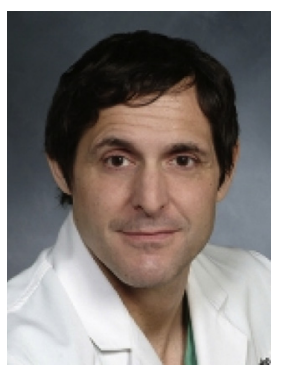

\section{REPLY FROM THE AUTHOR: TREATMENT OF LEFT MAIN CORONARY ARTERY DISEASE: OLD HABITS DIE HARD}

Reply to the Editor:

The letter by Gomes ${ }^{1}$ is an important reminder of the pathophysiologic reasons why left main coronary artery disease (LMC) should not be seen as a separate entity and should instead be considered as part of multivessel coronary disease. The concept of LMC as a separate entity comes from an era when, due to the limited efficacy of medical therapy for secondary prevention and of the revascularization procedures, the risk of acute coronary or graft occlusion was not negligible and lesions in the LMC were at very high risk of clinical events. In the current era, the risk is considerably lower and in patients in whom LMC is combined with multivessel disease (the great majority, as pointed out by Gomes), the latter should determine the therapeutic approach.
The concept of a different treatment for LMC was generated in a subgroup analysis of the SYNTAX (Synergy between Percutaneous Coronary Intervention with Taxus and Cardiac Surgery) trial ${ }^{2}$ and subsequently rejected by NOBLE (Nordic-Baltic-British Left Main Revascularization) and EXCEL (Evaluation of XIENCE versus Coronary Artery Bypass Surgery for Effectiveness of Left Main Revascularization). ${ }^{3,4}$ It is time for the cardiovascular community to leave the old habits and start treating the patients on the basis of the most recent evidence.

\section{Mario Gaudino, MD \\ Department of Cardiothoracic Surgery Weill Cornell Medicine \\ New York, NY}

\section{References}

1. Gomes WJ. Left main coronary artery stenosis: evidence and pathophysiology J Thorac Cardiovasc Surg. 2020 [Epub ahead of print].

2. Serruys PW, Morice MC, Kappetein AP, Colombo A, Holmes DR, Mack MJ et al. Percutaneous coronary intervention versus coronary-artery bypass grafting for severe coronary artery disease. $N$ Engl J Med. 2009;360: 961-72.

3. Mäkikallio T, Holm NR, Lindsay M, Spence MS, Erglis A, Menown IBA et al. Percutaneous coronary angioplasty versus coronary artery bypass grafting in treatment of unprotected left main stenosis (NOBLE): a prospective, randomised, open-label, non-inferiority trial. Lancet. 2016; 388:2743-52.

4. Stone GW, Kappetein AP, Sabik JF, Pocock SJ, Morice M, Puskas J, et al Five-year outcomes after PCI or CABG for left main coronary disease. $N$ Engl $J$ Med. 2019;381:1820-30

https://doi.org/10.1016/j.jtcvs.2020.05.104 